\title{
A deterministic approach to a capital budgeting problem
}

\author{
Akpan, N. P and Etuk, E. H and Essi, I.D \\ Department of Mathematics and Statistics, University of Port Harcourt, Port Harcourt, \\ Rivers State, Nigeria
}

\begin{abstract}
The purpose of this paper is to model capital budgeting of Akwa Ibom State, Nigeria. The exact approach is employed in solving the problem and the optimal solution was obtained. The capital projects are summarized in four broad groups: the economic sector $\left(x_{1}\right)$, the social service sector $\left(x_{2}\right)$, the environmental regional development sector $\left(x_{3}\right)$, and the Administration sector $\left(x_{4}\right)$. It was observed that sector 1 and sector 4 will not be selected, and whereas sector 2 and 3 will be selected $\left(x_{1}, x_{4}=0 ; x_{2}, x_{3}=1\right)$. The optimal solution value is 129.7600 . A MATLAB of version 7.1 was used for the Analysis.
\end{abstract}

Keywords: Capital Budgeting, Knapsack Problem, Deterministic technique, Capital Projects, Linear Programming.

\section{INTRODUCTION:}

Capital budgeting is an aspect of a knapsack problem known as the multi dimensional knapsack problem. The model selects a maximum value of projects, investments, and so on, subject to limitations on budgets or other resources consumed, Rardin (1998). The concept has a broad application in different sectors of human live.

Capital budgeting can be seen as an approach or way of making a good choice of investments with satisfactory cash flow and rate of return. It is obvious that in any organization/firm, the object is to maximize the profit and minimize the cost; for this objective to be achieved, the management should be able to take a right decision on which investment to embark on given other alternatives. This process of evaluating, comparing and selecting the needed project given the limited resources is called Capital Budgeting. In support of this Dayananda et al., (2002) defines Capital budgeting to be the process of determining which investment projects result maximizes the shareholders value.

Here, we shall consider the capital budget from the governmental spending point of view, where Capital refers to an investment in goods or services that provide benefits over a period of the time after their acquisition. Although specific definitions of capital can vary significantly depending on the purpose, some definitions focus narrowly on physical infrastructure, such as high ways and buildings; others focus more broadly and include intangibles, such as education and social services.

In Nigeria, we operate on three-tier structure of government; the Federal, the State and the Local Government. Each of which must have its capital budget for each fiscal year. In this work, we are interested in the capital budget of the second structure of government (state government)

Although, the State budget presents the state government's expenditures and revenue for each fiscal year, it also enables policy makers to allocate resources to serve certain objectives, and gives the treasury needed information for its management of cash and the public debt. It is based on this that we are motivated to take a decision on the four sectors of the capital projects, which is an embodiment of projects to be considered bearing in mind, the allocation given to the State and the internal generated revenue so as to ensure maximum comfort to the citizens.

\section{ASSUMPTIONS}

(1) All the projects are independent of each other

(2) All the sectors have equal importance to the development of the State.

The study of capital budgeting is so broad, and as such researchers have come out with various 
contributions in the area. Weingartner (1963) and Von Randow (1982) observed that the Capital budgeting problem context has been extensively studied. Following Weingartner's (1963) work on capital budgeting problems an extensive literature was developed on the mathematical approaches to capital budgeting problems using linear programming, goal programming, nonlinear programming, mixed integer programming and simulation; see Bilici \& Benli (2006). Mc Carl \& Spreen (2003) stated that capital budgeting involves selection of the most valuable investments from a set of available, but indivisible, investments subject to limited capital availability.

The traditional theory of capital budgeting uses a single objective, usually in the form of a maximization of company's revenues. In the late nineteen sixties and early nineteen seventies researchers proposed to extend the traditional model with multiple objectives, as the particular projects can be selected with respect to more than a single objective, see Ansoff (1968). Capital budgeting with multiple objectives was also studied by Lee \& Lerro (1974). Hawkins \& Adams (1974) proposed a goal programming model of capital budgeting.

Natalie (2003) defines Capital budgeting as the part of the budget process that focuses on the recourse plant for building new facilities, renovating existing facilities, buying major piece of equipments or improving the campus infrastructure. He further States that a capital budget typically has a long term horizon a minimum of five years because the expenditures are for investments in assets that are expected to benefit for more than one year. Dayananda et al., (2002) stated that capital budgeting is primarily concerned with sizable investments in long term assets. These assets may be tangible items such as property, plant and equipment or intangible ones such as new technology, patent or trademarks.

According to Bilici \& Benli (2006), capital budgeting is one of the first kinds of integer programming problems studied. It was first posed by Lorie and Savage (1955) as

$$
\operatorname{Max} \quad \sum_{j=1}^{n} c_{j} x_{j}
$$

$$
\begin{gathered}
\text { s.t } \quad \sum_{j=1}^{n} a_{j} x_{j} \leq b \\
x_{j}=0 \text { or } 1
\end{gathered}
$$

where $n$ projects are under consideration, and $\mathbf{c}_{j}$ is the net present value of project $\mathbf{j}$, and $\mathbf{a}_{\mathbf{j}}$ is the capital required to fund project $\mathbf{j}$. The total capital available for all projects is $\mathbf{b}$. The decision variable, $\mathbf{x}_{\mathbf{j}}$ is equal to one if project $\mathrm{j}$ is selected and zero otherwise

Philippatos (1991) defined capital budgeting as concerned with the allocation of a firm's scarce resources among the available investment opportunities. Bean et al (1987) solved a multi-period version of the problem where the objective was to maximize net present value profit by divesting assets subject to certain lower bounds on equity that companies must achieve each year. Also Bhargava (1992) discussed the fleet mix planning of the U.S Coast as a capital budgeting problem. Jindriska \&Milos (2008) stated that for small instances of the capital budgeting problem, the solver nested in Microsoft Excel can be used, which can be applied to simple tasks of linear and integer programming. $\mathrm{He}$ also added that task for higher number of inputs, where, to a certain extent, a more sophisticated software tools such as GAMS, LINDO \& LINGO is recommended. He further observed that GAMS and Excel are not effective in solving very complex multiperiod capital budgeting problems.

Aim of the research: Naturally, Government's responsibility is always to subsidize/provide for its citizen. As such, during this process that government is trying to provide or her citizen, the government is bound to select or choose from all the services needed in different sectors, which among them that he will want to invest in/satisfy. This can be achieved by either minimizing the cost such that it invests in as much project as possible given the limited resources or maximizes the values of the projects. Here our interest is on maximizing the values of the projects.

The model: Capital budgeting models select a maximum value collection of project, investment and so on, subject to limitations on budgets or other resources consumed; see Rardin (1998). Consider the table below 
Am. J. Sci. Ind. Res., 2011, 2(3): 456-460

\section{BUDGET REQUIREMENT}

SECTORS

$\begin{array}{rrrrr}1 & \mathrm{C}_{11} & \mathrm{C}_{12} & \mathrm{C}_{13} \\ \text { YEARS } & 2 & \mathrm{C}_{21} & \mathrm{C}_{22} & \mathrm{C}_{23} \\ & 3 & \mathrm{C}_{31} & \mathrm{C}_{32} & \mathrm{C}_{33} \\ \mathrm{~m} & \mathrm{C}_{\mathrm{m} 1} & \mathrm{C}_{\mathrm{m} 2} & \mathrm{C}_{\mathrm{m} 3}\end{array}$

$\begin{array}{ll}\mathrm{C}_{1 \mathrm{n}} & \mathrm{A}_{1} \\ \mathrm{C}_{2 \mathrm{n}} & \mathrm{A}_{2} \\ \mathrm{C}_{3 \mathrm{n}} & \mathrm{A}_{3}\end{array}$

we aim at selecting at least a sector from each year in such a way that the total cost of executing projects in a certain year does not exceed the total allocation

$$
\begin{aligned}
& \text { Max } Z=\sum_{j=1}^{n} V_{j} x_{j} \\
& \text { S.t } \quad \sum_{j=1}^{n} C_{i j} x_{j} \leq A_{i}, \quad i=1,2 ., \ldots, m
\end{aligned}
$$

Where $A_{j}$ is the total budget for the $\mathrm{n}$ projects in all the sectors for the jth year.

$$
\begin{aligned}
& C_{i j} \text { is the cost of executing project } \mathrm{j} \text { in year } \mathrm{i} \\
& V_{j} \text { is the value for projects in sector } \mathrm{j} \\
& x_{j} \text { is the binary variable. }
\end{aligned}
$$

Therefore we can now present the formulation of capital budgeting of the above table as

or assigning to capital budget for that year such that the value of that sector is maximized. That is:

$$
\begin{aligned}
& \operatorname{Max} Z=V_{1} x_{1}+V_{1} x_{1}+V_{1} x_{1}+. \quad+\quad+V_{n} x_{n} \\
& \text { S.t } \quad C_{11} x_{1}+C_{12} x_{2}+C_{13} x_{3}+. . \quad+C_{1 n} x_{n} \\
& \leq \quad A_{1} C_{21} x_{1}+C_{22} x_{2}+C_{23} x_{3}+.+C_{2 n} x_{n} \\
& \leq \quad A_{2} \\
& \quad C_{m 1} x_{1}+C_{m 2} x_{2}+C_{m 3} x_{3}+. .+C_{m n} x_{n} \\
& \leq \quad A_{m}
\end{aligned}
$$

\section{OPTIMAL SOLUTION}

Since the problem is a multi-constraint problem, we shall present the model by adopting the simplex approach that was developed by Dantzik. We shall make use of ten constraints representing the ten years considered and four non-basic variables representing the four sectors of the capital projects budgeting. Let the initial iteration table be as shown below:

\section{INITIAL ITERATION TABLE}

\begin{tabular}{|l|l|l|l|l|l|l|l|l|l|l|l|l|l|l|l|l|}
\hline \multirow{2}{*}{$\mathrm{C}_{\mathrm{B}}$} & & $\mathrm{V}_{1}$ & $\mathrm{~V}_{2}$ & $\mathrm{~V}_{3}$ & $\mathrm{~V}_{4}$ & 0 & 0 & 0 & 0 & 0 & 0 & 0 & 0 & 0 & 0 & \\
& & $\mathrm{X}_{1}$ & $\mathrm{x}_{2}$ & $\mathrm{x}_{3}$ & $\mathrm{x}_{4}$ & $\mathrm{~S}_{1}$ & $\mathrm{~S}_{2}$ & $\mathrm{~S}_{3}$ & $\mathrm{~S}_{4}$ & $\mathrm{~S}_{5}$ & $\mathrm{~S}_{6}$ & $\mathrm{~S}_{7}$ & $\mathrm{~S}_{8}$ & $\mathrm{~S}_{9}$ & $\mathrm{~S}_{10}$ & Constant \\
\hline $\mathrm{C}_{\mathrm{B}}$ & Basic & & & & & & & & & & & & & & & \\
\hline & $\mathrm{S}_{1}$ & $\mathrm{C}_{11}$ & $\mathrm{C}_{12}$ & $\mathrm{C}_{13}$ & $\mathrm{C}_{14}$ & 1 & 0 & 0 & 0 & 0 & 0 & 0 & 0 & 0 & 0 & \\
\hline & $\mathrm{S}_{2}$ & $\mathrm{C}_{21}$ & $\mathrm{C}_{22}$ & $\mathrm{C}_{23}$ & $\mathrm{C}_{24}$ & 0 & 1 & 0 & 0 & 0 & 0 & 0 & 0 & 0 & 0 & \\
\hline & $\mathrm{S}_{3}$ & $\mathrm{C}_{31}$ & $\mathrm{C}_{32}$ & $\mathrm{C}_{33}$ & $\mathrm{C}_{34}$ & 0 & 0 & 1 & 0 & 0 & 0 & 0 & 0 & 0 & 0 & \\
\hline & $\mathrm{S}_{4}$ & $\mathrm{C}_{41}$ & $\mathrm{C}_{42}$ & $\mathrm{C}_{43}$ & $\mathrm{C}_{44}$ & 0 & 0 & 0 & 1 & 0 & 0 & 0 & 0 & 0 & 0 & \\
\hline & $\mathrm{S}_{5}$ & $\mathrm{C}_{51}$ & $\mathrm{C}_{52}$ & $\mathrm{C}_{53}$ & $\mathrm{C}_{54}$ & 0 & 0 & 0 & 0 & 1 & 0 & 0 & 0 & 0 & 0 & \\
\hline & $\mathrm{S}_{6}$ & $\mathrm{C}_{61}$ & $\mathrm{C}_{62}$ & $\mathrm{C}_{63}$ & $\mathrm{C}_{64}$ & 0 & 0 & 0 & 0 & 0 & 1 & 0 & 0 & 0 & 0 & \\
\hline & $\mathrm{S}_{7}$ & $\mathrm{C}_{71}$ & $\mathrm{C}_{72}$ & $\mathrm{C}_{73}$ & $\mathrm{C}_{74}$ & 0 & 0 & 0 & 0 & 0 & 0 & 1 & 0 & 0 & 0 & \\
\hline & $\mathrm{S}_{8}$ & $\mathrm{C}_{81}$ & $\mathrm{C}_{82}$ & $\mathrm{C}_{83}$ & $\mathrm{C}_{84}$ & 0 & 0 & 0 & 0 & 0 & 0 & 0 & 1 & 0 & 0 & \\
\hline & $\mathrm{S}_{9}$ & $\mathrm{C}_{91}$ & $\mathrm{C}_{92}$ & $\mathrm{C}_{93}$ & $\mathrm{C}_{94}$ & 0 & 0 & 0 & 0 & 0 & 0 & 0 & 0 & 1 & 0 & \\
\hline & $\mathrm{S}_{10}$ & $\mathrm{C}_{101}$ & $\mathrm{C}_{102}$ & $\mathrm{C}_{103}$ & $\mathrm{C}_{104}$ & 0 & 0 & 0 & 0 & 0 & 0 & 0 & 0 & 0 & 1 & \\
\hline \multicolumn{2}{c}{$\overline{\mathrm{G}}$ row } & & & & & & & & & & & & & & & \\
\hline
\end{tabular}


Sector 1, $\left(x_{1}\right)$ is made up of Agriculture, Livestock \& Veterinary Service, Forestry, Fisheries, Manufacturing/Craft, Urban Electrification, Commerce \& Tourism, Works \& Transport.

Sector 2, $\left(x_{2}\right)$ is made up of Education, Science \& Technology, Health, Information, Culture, Youth \& Sports, Social Development, Water Supply (urban), Rural Development \& Utilities.

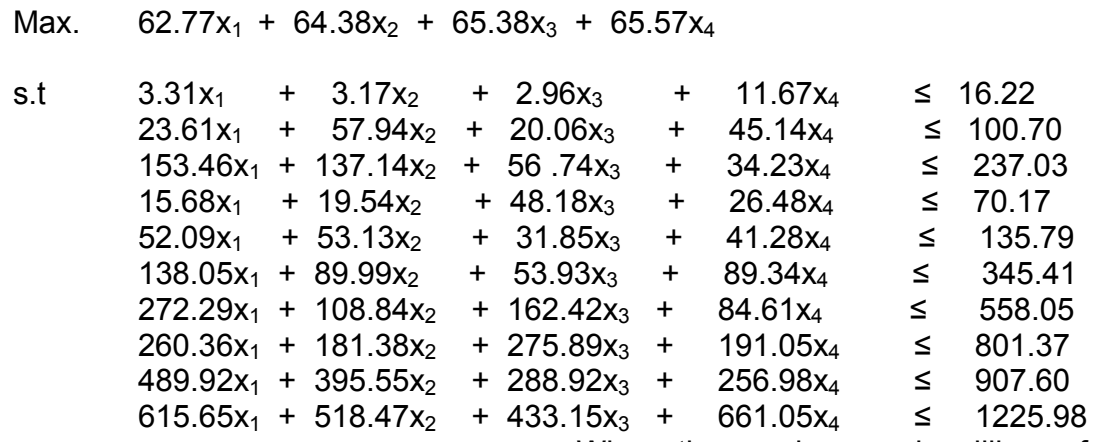

Sector 3, $\left(x_{3}\right)$ is made up of Sewage, Drainage and Refuge Disposal, Housing, Urban Development.

Sector $4,\left(x_{4}\right)$ is made up of General Administration, Judiciary-General Administration, House of AssemblyGeneral Administration.

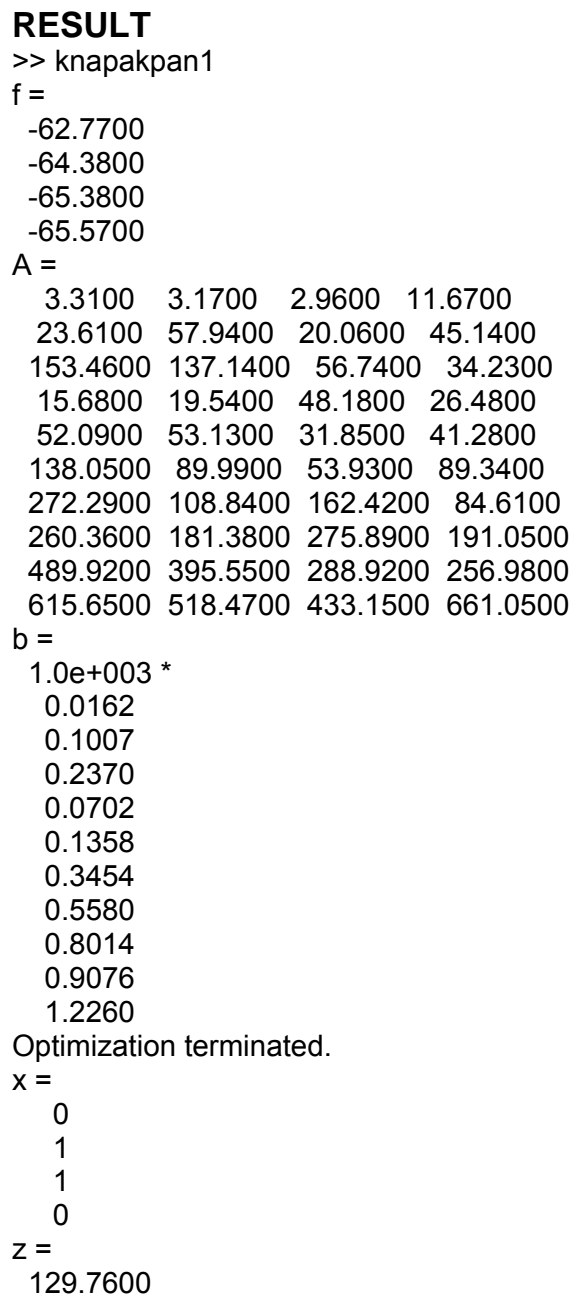

Where these values are in millions of naira. 


\section{CONCLUSION}

A deterministic technique was employed to carry out the analysis. The 17.7 version of Matlab was used and the output shows that sector 1 and sector 4 will not be selected, and whereas sector 2 and 3 will be selected $\left(x_{1}, x_{4}=0 ; x_{2}, x_{3}=1\right)$. The optimal solution value is 129.7600 million naira. This means, it is 129.7600 million naira that is required to execute the projects and maximize their values.

\section{REFERENCES}

ANSOFF, H.T(1968), Corporate Strategy. Penguin .

BEAN, J. C, NOON, C. E. and SALTON, G.J (1987): Asset Divestiture at Homart Development. Interfaces 17(1);48-64

BHARGAVA, H. K. (1992); Fleet Mix Planning in the U.S Coast Guard: Issues and challenges for DSS. In A.B Whinston, editor, Recent Developments in DSS. Springer-Verlag, New York.

BILICI HAMDI \& BENLI OMER (2006); Capital budgeting with Risk Adjustment for large scale interdependent projects. Review of social, Economic and business studies, Vol.7/8, 71-82.

DAYANANDA, D., IRONS, R., HARRISON, S., HERBOHN, J. \& ROWLAND, P. (2002): Financial Appraisal of investment projects, Cambridge University Press, Edinburgh.
HAWKINS, C.A \& ADAMS, R.A (1974): A Goal Programming Model for Capital Budgeting. Journal of Financial Management.

JINDRISKA SEDOVA, \& MILOS SEDA (2008); A comparison of Exact and Heuristic Approaches to capital Budgeting. Proceeding of World Academy of Sciences, Engineering and Technology Vol.35 ISSN $2070-3740$.

LEE, S. M \& LERRO, A. J. (1974): Capital Budgeting for multiple objective. Management Science, Vol 36. Pp $1106-1119$

LORIE, J.H. \& SAVAGE, L. J (1955): Three Problems in Capital Rationing. Journal of Bus. 28, 229-239

Mc CARL, B.A \& SPREEN, T.H(2003) Applied Mathematical Programming Using Algebraic Systerm.

NATALIE KRAWITZ (2003),Department Leadership Projects. http//www.acenet.edu/resources/chairs/

PHILLIPPATOS, G.C. (1991), Financial Management: Text and Cases. Allyn \& Bacon.

RARDIN, R.L (1998): Optimization in Operations Research. Prentice Hall Inc.

VON RANDOW,R.(1982), Integer Programming and Related Areas - A Classified Bibliography 1978-1981. Springer-Verlag, New York.

WEINGARTNER, H.M (1963), Mathematical Programming and the Analysis of Capital Budgeting Problems. Engle wood Cliffs, N.J: Prentice - Hall 